\title{
KARAKTERISTIK PEWARNA ALAMI DARI EKSTRAK KULIT BUAH JERUK MANDARIN (Citrus reticulata) PADA PERBANDINGAN PELARUT ETANOL DAN KLOROFORM
}

\author{
The Effect of Ethanol and Chloroform Solvent Ratio to The Natural Colorant Characteristic \\ of The Mandarin Orange Peel (Citrus reticulata) Extract.
}

\author{
Sagung Ayu Bulan Julia Saraswati, Luh Putu Wrasiati*, Ni Made Wartini \\ PS Teknologi Industri Pertanian, Fakultas Teknologi Pertanian, Universitas Udayana, Kampus Bukit \\ Jimbaran, Badung, Kode pos : 80361; Telp/Fax : (0361) 701801.
}

Diterima 14 September 2018 / Disetujui 18 September 2018

\begin{abstract}
Orange fruit who be the superior commodity is known as a fruit who rich of its vitamin C. One kind of orange who really liked by the society is Mandarin Orange (Citrus reticulata) that comes from China. The aims of this research were to know the effect of ethanol and chloroform solvent ratio to the characteristic of the natural colorant from Mandarin orange peel extract and determine the best ethanol and chloroform solvent ratio which produced Mandarin orange peel extract as natural colorant. Experimental design in this research used Randomized Block Design by using the comparison of ethanol and chloroform solvents that consist of 6 levels, there are: ethanol : chloroform (0:10); ethanol : chloroform (2:8); ethanol : chloroform (4:6); ethanol : chloroform (6:4); ethanol : chloroform (8:2); ethanol: chloroform (10:0). The treatment was repeated as many as 3 repetitions then obtained 18 units of the experiment. The data were analyzed by variance and if the treatment had a effect on the variable then continued with Duncan test. The result showed that ethanol and chloroform solvent ratio had significant effect on the yield, the total carotenoids content, the level of brightness $\left(L^{*}\right)$, the level of redness $\left(a^{*}\right)$, the level of yellowness $\left(b^{*}\right)$ of Mandarin orange peel extract. Based on the results of index effectiveness test used five expert, the ethanol and chloroform solvent ratio of $0: 10$ produced the best characteristic of Mandarin orange peel extract with the yield $4.83 \pm 0.22 f(\%)$, the total carotenoids content $3.56 \pm 0.20 a(\%)$, the level of brightness $\left(L^{*}\right) 31.34 \pm 0.63 d$, the level of redness $\left(a^{*}\right) 28.39 \pm$ $0.69 a$, and the level of yellowness $\left(b^{*}\right) 34.52 \pm 0.18 a$.
\end{abstract}

Keywords : Citrus reticulata, extraction, ethanol, chloroform, natural colorant

\begin{abstract}
ABSTRAK
Buah jeruk yang menjadi komoditi unggulan, dikenal kaya akan kandungan vitamin $\mathrm{C}$ nya. Salah satu jenis buah jeruk yang banyak digemari oleh masyarakat yaitu buah jeruk Mandarin (Citrus reticulata) yang berasal dari negeri Cina. Tujuan dari penelitian ini adalah untuk mengetahui pengaruh perbandingan pelarut etanol dan kloroform terhadap karakteristik pewarna alami ekstrak kulit buah jeruk Mandarin dan untuk menentukan perbandingan pelarut etanol dan kloroform terbaik yang dapat menghasilkan ekstrak kulit buah jeruk Mandarin sebagai perwarna alami. Rancangan percobaan penelitian ini menggunakan Rancangan Acak Kelompok dengan perlakuan perbandingan jenis pelarut etanol dan kloroform yang terdiri atas 6 taraf yaitu: etanol : kloroform (0:10); etanol : kloroform (2:8);
\end{abstract}

*Korespondensi Penulis:

Email: wrasiati@unud.ac.id 
etanol : kloroform (4:6); etanol : klorofrom (6:4); etanol : kloroform (8:2); etanol : klorofrom (10:0). Perlakuan dikelompokkan menjadi 3 kelompok sehingga didapat 18 unit percobaan. Data dianalisis dengan sidik ragam dan apabila perlakuan berpengaruh terhadap variabel maka dilanjutkan dengan uji Duncan. Hasil penelitian menunjukkan bahwa perbandingan pelarut etanol dan kloroform berpengaruh sangat nyata terhadap rendemen, kadar karotenoid, tingkat kecerahan, tingkat kemerahan, dan tingkat kekuningan ekstrak kulit buah jeruk Mandarin. Berdasarkan hasil uji indeks efektivitas menggunakan 5 orang pakar, perbandingan etanol dan kloroform $(0: 10) \mathrm{v} / \mathrm{v}$ merupakan perlakuan terbaik untuk menghasilkan ekstrak kulit buah jeruk Mandarin dengan karakteristik rendemen 4,83 $\pm 0,22$ (\%), kadar total karotenoid 3,56 $\pm 0,20(\%)$, tingkat kecerahan $\left(\mathrm{L}^{*}\right) 31,34 \pm 0,63$, tingkat kemerahan (a*) 28,39 \pm 0,69 , dan tingkat kekuningan $(b *) 34,52 \pm 0,18$.

Kata kunci : Citrus reticulata, ekstraksi, etanol, kloroform, pewarna alami.

\section{PENDAHULUAN}

Buah jeruk merupakan salah satu buah yang banyak dikonsumsi di Indonesia. Buah yang menjadi komoditi unggulan ini dikenal kaya akan kandungan vitamin $\mathrm{C}$ nya. Salah satu jenis buah jeruk yang banyak digemari oleh masyarakat yaitu buah jeruk Mandarin (Citrus reticulata). Pada umumnya, yang dimanfaatkan dari buah jeruk adalah daging buahnya. Disamping daging buahnya, kulit buah jeruk berpotensi sebagai sumber antioksidan dan pewarna alami. Kulit buah jeruk banyak mengandung senyawa flavonoid seperti hesperidin, naringin dan flavonoid polimetoksi seperti tangeritin dan nobiletin (Nogata et al., 2006).

Saat ini kulit buah jeruk Mandarin belum termanfaatkan dengan baik. Toko buah maupun penjual jus dan salad buah di Denpasar belum memanfaatkan limbah kulit buah jeruk Mandarin yang dihasilkan. Dilihat dari warna kulit buah jeruk Mandarin yang berwarna oranye diduga bahwa kulit buah jeruk Mandarin mengandung senyawa karotenoid. Kulit buah jeruk tersebut memiliki potensi yang sangat besar untuk diolah menjadi ekstrak pewarna baik untuk pangan, industri tekstil maupun kosmetik.

Zat pewarna dihasilkan dari bahan alami dan bahan sintetis. Namun, saat ini penggunaan zat pewarna pangan banyak yang berasal dari bahan sintetis. Pewarna sintetis apabila dikonsumsi terus-menerus pada jumlah berlebihan akan terakumulasi dalam tubuh dan berpotensi menyebabkan kanker. Oleh karena itu perlu dicari alternatif sumber pewarna alami yang aman untuk dikonsumsi. Melihat potensi dari kulit buah jeruk Mandarin yang dapat dimanfaatkan sebagai pewarna, maka dilakukan ekstraksi kulit buah jeruk Mandarin untuk mendapatkan senyawa karotenoid yang dapat berfungsi sebagai pewarna alami.Ekstraksi senyawa pewarna alami dipengaruhi oleh suhu, waktu, metode dan pelarut. Suatu senyawa akan mudah larut dalam pelarut yang mempunyai polaritas yang sama atau mirip dengan senyawa tersebut (Sudarmadji et al., 1989).

Beberapa penelitian sebelumnya mengenai ekstraksi karotenoid menggunakan perbandingan jenis pelarut yang berbeda seperti ekstraksi karotenoid pada buah pandan menggunakan kombinasi pelarut aseton-kloroform dan aseton-etanol (Isadora et al. 2016), ekstraksi karotenoid pada ubi jalar menggunakan perbandingan pelarut etanol : aseton (Ginting, 2013), ekstraksi karotenoid pada sari buah merah menggunakan kombinasi pelarut aseton, kloroform, dan n-heksana (Sundari, 2008),

Penelitian Sari et al. (2015) mengenai pengaruh jenis pelarut terhadap rendemen dan karakteristik ekstrak pewarna dari buah pandan menggunakan pelarut tunggal menunjukan bahwa jenis pelarut etil asetat menghasilkan ekstrak buah pandan dengan kadar total karotenoid tertinggi $(0,17 \%)$ tidak berbeda nyata dengan kloroform $(0,12 \%)$ dan aseton $(0,12 \%)$. Hasil penelitian tersebut 
berdasarka uji indeks efektivitas diperoleh perlakuan terbaik yaitu pelarut klorofrom. Penelitian Silalahi et al. (2014) mengenai ekstrak kulit buah jeruk Mandarin sebagai bahan baku perisa pangan dengan menggunakan metode maserasi menunjukkan bahwa perlakuan terbaik untuk menghasilkan bubuk ekstrak kulit buah jeruk Mandarin adalah lama maserasi 6 jam menggunakan pelarut etanol dan konsentrasi maltodekstrin $10 \%$. Saat ini belum dilakukan penelitian mengenai ekstrak kulit buah jeruk Mandarin yang dimanfaatkan sebagai pewarna alami. Perbandingan jenis pelarut yang terbaik untuk menghasilkan ekstrak kulit buah jeruk Mandarin juga belum diketahui. Tujuan melakukan pencampuran jenis pelarut yang berbeda ini adalah untuk mengatur polaritas.

Berdasarkan hal tersebut, maka penelitian dengan tujuan untuk mengetahui pengaruh perbandingan pelarut etanol dan kloroform terhadap karakteristik pewarna alami ekstrak kulit buah jeruk Mandarin serta untuk menentukan perbandingan jenis pelarut terbaik yang dapat menghasilkan pewarna alami ekstrak kulit buah jeruk Mandarin perlu dilakukan.

\section{METODE PENELITIAN}

\section{Bahan dan Alat}

Bahan-bahan yang digunakan dalam melaksanakan penelitian ini terdiri dari limbah kulit buah jeruk Mandarin berwarna oranye yang diperoleh dari toko buah "Moena Fresh" yang menyediakan produk salad buah, etanol teknis, kloroform pa (Merck), petroleum benzene (Merck), aseton (Merck), dan $\mathrm{Na}_{2} \mathrm{SO}_{4}$ (Merck) yang diperoleh dari toko bahan kimia.

Peralatan yang digunakan dalam melaksanakan penelitian ini terdiri dari oven pengering (Ecocell), blender (Phillips HR 2115), ayakan 60 mesh, kertas saring kasar, kertas Whatman no. 1, rotary evaporator (IKA $R V 10$ basic), spektrofotometer (Genesys 105
$U V$-VIS), vortex (Barntard Thermolyne Maxi Mix II), aluminium foil, pisau, kertas label, timbangan analitik (Shimadzu), gelas ukur (pyrex), corong pemisah, labu ukur (Pyrex), labu erlenmeyer (Pyrex), botol sampel.

\section{Pelaksanaan Penelitian}

Kulit buah jeruk Mandarin dicuci, kemudian ditiriskan. Selanjutnya dipotongpotong dengan ukuran sekitar $2 \mathrm{~cm} \times 2 \mathrm{~cm}$ untuk mempermudah pengeringan dan penghancuran bahan. Potongan kulit buah jeruk Mandarin dimasukan ke dalam oven dengan suhu $60 \pm 5{ }^{\circ} \mathrm{C}$ selama 24 jam (Berutu, 2013). Kemudian kulit buah jeruk Mandarin dimasukan ke dalam blender untuk dihancurkan hingga halus. Bubuk kulit buah jeruk Mandarin diayak menggunakan ayakan 60 mesh. Selanjutnya ditimbang sebanyak 10 g, kemudian dimasukan ke dalam labu Erlenmeyer. Disiapkan pelarut campuran etanol dan kloroform sesuai perlakuan. Ditambahkan pelarut etanol teknis dan kloroform PA sebanyak $100 \mathrm{ml}$ (perbandingan bahan dengan pelarut ialah 1 : 10). Selanjutnya, dimaserasi 6 jam dengan suhu ruang. Setelah itu, dilakukan pengadukan secara manual setiap 30 menit selama 5 menit, sehingga diperoleh ekstrak bercampur pelarut. Larutan disaring menggunakan kertas saring kasar untuk menyaring ampas yang berukuran besar, sehingga menghasilkan filtrat I. Ampas basah yang dihasilkan, ditambahkan pelarut sebanyak $100 \mathrm{ml}$ sesuai perlakuan. Selanjutnya proses maserasi diulang dengan tahapan yang sama, kemudian disaring menggunakan kertas saring sehingga menghasilkan filtrat II. Filtrat I dan filtrat II dicampur, kemudian disaring menggunakan kertas Whatman no. 1. Selanjutnya dievaporasi dengan menggunakan rotary evaporator untuk menghilangkan pelarut pada suhu $40{ }^{\circ} \mathrm{C}$ dengan tekanan $100 \mathrm{mBar}$ sampai seluruh pelarut menguap, ditunjukkan dengan pelarut tidak menetes lagi pada labu 
alas bulat.

\section{Variabel yang Diamati}

Variabel yang diamati pada ekstrak kulit buah jeruk Mandarin adalah rendemen (AOAC, 1999), kadar total karotenoid (Muchtadi, 1989), dan intensitas warna (system L, a, b dalam Weaver, 1996).

\section{HASIL DAN PEMBAHASAN}

\section{Rendemen (\%)}

Hasil analisis ragam menunjukkan bahwa perlakuan perbandingan pelarut etanol dan kloroform berpengaruh nyata $(\mathrm{P}<0,05)$ terhadap rendemen ekstrak kulit buah jeruk Mandarin. Nilai rata-rata rendemen ekstrak kulit buah jeruk Mandarin dapat dilihat pada Gambar 2.

Gambar 2 menunjukkan bahwa pada perlakuan perbandingan pelarut etanol dan kloroform (v/v) EK6 (10 : 0) dengan konstanta dielektrikum 24,30 menghasilkan rendemen ekstrak kulit buah jeruk Mandarin yang paling tinggi, yaitu $36,99 \%$. Sedangkan perlakuan perbandingan pelarut etanol dan kloroform (v/v) EK1 (0 : 10) dengan konstanta dielektrikum 6,02 menghasilkan rendemen ekstrak yang paling rendah, yaitu 4,83\%. Hal tersebut menunjukkan bahwa kepolaran senyawa yang terkandung dalam kulit buah jeruk Mandarin mendekati kepolaran pelarut etanol sehingga terekstrak paling banyak. Pelarut dapat mengekstrak senyawa-senyawa yang memiliki kepolaran yang sama atau mirip dengan pelarut yang digunakan (Adiyasa et al., 2015). Hal ini sesuai dengan hasil penelitian Sari et al. (2015) yang menunjukkan bahwa nilai ratarata rendemen ekstrak buah pandan menggunakan pelarut etanol lebih tinggi dibandingkan dengan menggunakan pelarut kloroforom.

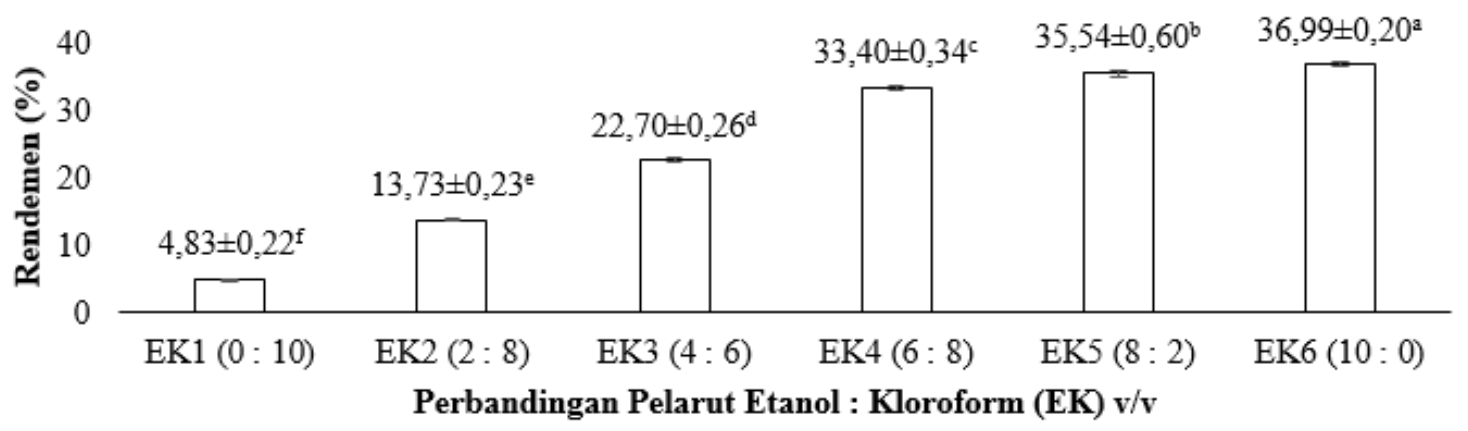

Gambar 2. Grafik nilai rata-rata rendemen ekstrak kulit buah jeruk Mandarin (\%).

\section{Total Karotenoid (\%)}

Hasil analisis ragam menunjukkan bahwa perlakuan perbandingan pelarut etanol dan kloroform berpengaruh nyata $(\mathrm{P}<0,05)$ terhadap kadar total karotenoid ekstrak kulit buah jeruk Mandarin. Nilai rata-rata kadar total karotenoid ekstrak kulit buah jeruk Mandarin dapat dilihat pada Gambar 3.

Gambar 3 menunjukkan bahwa pada perlakuan perbandingan pelarut etanol dan kloroform (v/v) EK1 (0 : 10) dengan konstanta dielektrikum 6,02 menghasilkan kadar karotenoid ekstrak kulit buah jeruk
Mandarin yang tinggi yaitu sebesar 3,56\%. Sedangkan perlakuan perbandingan pelarut etanol dan kloroform (v/v) EK6 (10 : 0) dengan konstanta dielektrikum 24,30 menghasilkan kadar total karotenoid yang rendah, yaitu $0,65 \%$. Hal tersebut menunjukkan bahwa pelarut kloroform yang bersifat non polar dapat lebih banyak mengekstrak senyawa karotenoid yang bersifat non polar dibandingkan dengan pelarut etanol. Sesuai dengan pernyataan Shriner et al. (1980) yaitu di dalam proses ekstraksi suatu senyawa kimia, berlaku 
hukum like dissolves yaitu, dalam proses ekstraksi jika menggunakan pelarut polar maka akan melarutkan senyawa polar. Namun, apabila menggunakan pelarut non polar maka akan melarutkan senyawa non polar. Hasil penelitian ini sesuai dengan penelitian Sari et al. (2015) yaitu, pada penelitian tersebut penggunaan pelarut kloroform pada ekstraksi buah pandan menghasilkan total karotenoid yang lebih tinggi yaitu sebesar $0,116 \%$ dibandingkan dengan menggunakan pelarut etanol yang mehasilkan total karotenoid sebesar $0,100 \%$. Penelitian Husnah et al.(2009) menunjukkan bahwa pelarut kloroform lebih dapat mengekstrak senyawa karotenoid dibandingkan pelarut etanol pada ekstrak kasar buah pepino.

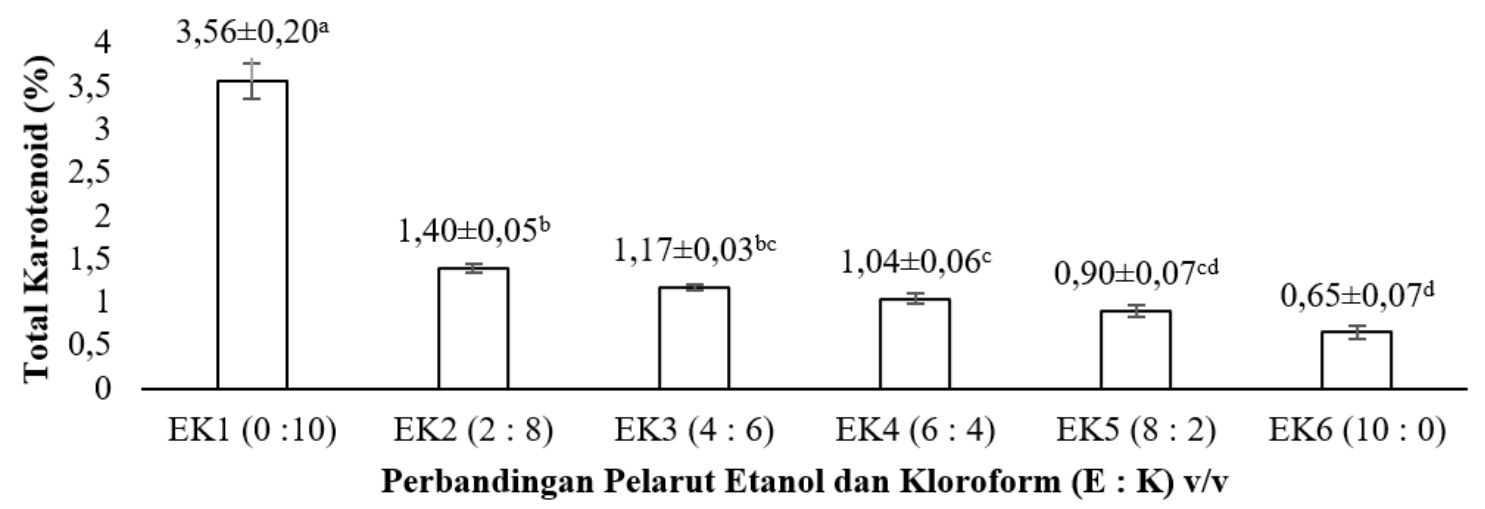

Gambar 3. Grafik nilai rata-rata total karotenoid ekstrak kulit buah jeruk Mandari (\%).

\section{Tingkat Kecerahan $\left(\mathrm{L}^{*}\right)$}

Hasil analisis ragam menunjukkan bahwa perlakuan perbandingan pelarut etanol dan kloroform berpengaruh nyata $(\mathrm{P}<0,05)$ terhadap tingkat kecerahan ekstrak kulit buah jeruk Mandarin. Nilai tingkat kecerahan $\left(\mathrm{L}^{*}\right)$ menyatakan tingkat gelap sampai terang dengan kisaran 0-100. Nilai rata-rata tingkat kecerahan ekstrak kulit buah jeruk Mandarin dapat dilihat pada Gambar 4.

Gambar 4 menunjukkan bahwa nilai ratarata tingkat kecerahan tertinggi diperoleh dari perlakuan perbandingan pelarut etanol dan kloroform (v/v) EK6 (10 : 0) dengan konstanta dielektrikum 24,30 dengan nilai rata-rata 45,88 tetapi tidak berbeda dengan perlakuan perbandingan pelarut etanol dan kloroform (v/v) EK5 (8: 2) yaitu 43,59. Sedangkan nilai rata-rata tingkat kecerahan terendah diperoleh dari perlakuan perbandingan pelarut etanol dan kloroform $(\mathrm{v} / \mathrm{v})$ EK1 (0 : 10) dengan konstanta dielektrikum 6,02 dan nilai rata-rata 31,34. Tingkat kecerahan yang dihasilkan pada penggunaan pelarut etanol lebih tingggi dibandingkan dengan penggunaan pelarut kloroform. Hal tersebut dikarenakan tingkat kecerahan memiliki kaitan dengan total karotenoid (Tabel 2) yang dihasilkan. Semakin tinggi kadar total karotenoidnya maka semakin pekat dan gelap hasil ekstrak yang dihasilkan sehingga tingkat kecerahannya rendah. Penelitian Isadora et al. (2016) menunjukkan bahwa tingkat kecerahan ekstrak buah pandan yang dihasilkan dari perlakuan kombinasi pelarut aseton dengan etanol lebih tinggi $(12,64)$ dibandingkan dengan kombinasi pelarut aseton dan kloroform $(7,74)$. 


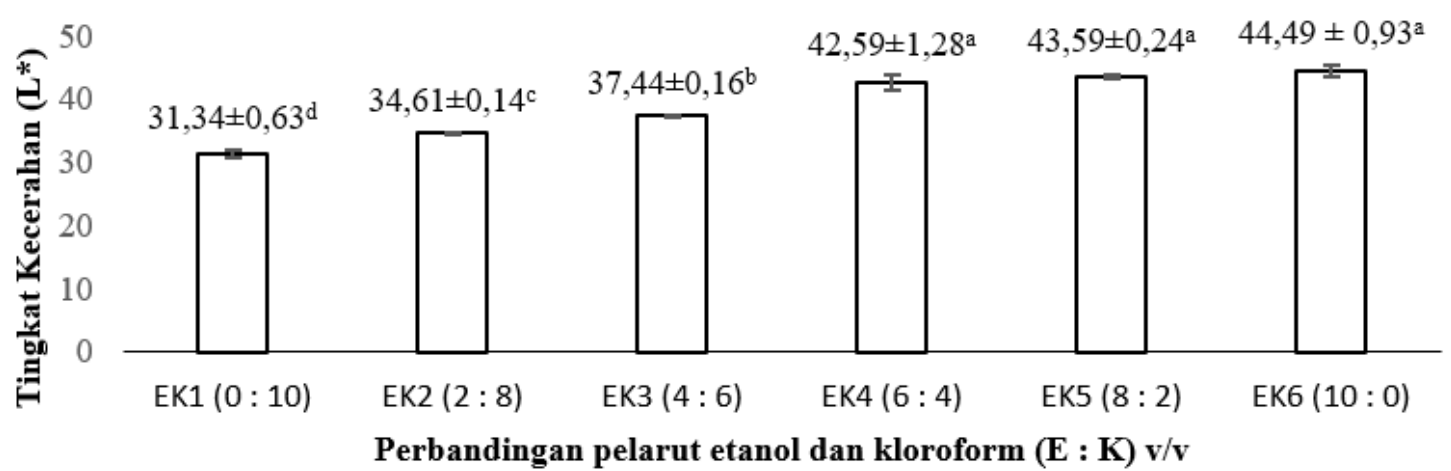

Gambar 4. Grafik nilai rata-rata tingkat kecerahan ekstrak kulit jeruk Mandarin.

\section{Tingkat Kemerahan ( $\left.\mathbf{a}^{*}\right)$}

Hasil analisis ragam menunjukkan bahwa perlakuan perbandingan pelarut etanol dan kloroform berpengaruh nyata $(\mathrm{P}<0,05)$ terhadap tingkat kemerahan ekstrak kulit buah jeruk Mandarin. Nilai tingkat kemerahan $\left(a^{*}\right)$ menyatakan tingkat warrna hijau sampai merah dengan kisaran -100 sampai +100. Nilai rata-rata tingkat kemerahan ekstrak kulit buah jeruk Mandarin dapat dilihat pada Gambar 5.

Gambar 5 menunjukkan bahwa nilai ratarata tingkat kemerahan tertinggi diperoleh dari perlakuan perbandingan pelarut etanol dan kloroform (v/v) EK1 (0 : 10) dengan konstanta dielektrikum 6,02 dengan nilai rata-rata 28,39. Sedangkan nilai rata-rata tingkat kemerahan terendah diperoleh dari perlakuan perbandingan pelarut etanol dan kloroform (v/v) EK4 (6:4) dengan konstanta dielektrikum 16,99 dan nilai rata-rata 23,86. Penelitian Isadora et al. (2016) menunjukkan bahwa tingkat kemerahan ekstrak buah pandan dari perlakuan kombinasi pelarut aseton dan etanol lebih tinggi $(4,15)$ dibandingkan dengan perlakuan kombinasi pelarut aseton dan kloroform $(-2,65)$. Terdapat hubungan antara tingkat kemerahan dengan semakin besarnya kelarutan karotenoid yaitu, semakin tinggi total karotenoid maka semakin tinggi pula tingkat kemerahannya (Satriyanto et al., 2012). Namun, pada perlakuan perbandingan etanol : kloroform 10 : 0 (EK 6) tingkat kemerahan yang dihasilkan tidak sesuai dengan pernyataan tersebut. Hal itu dapat disebabkan adanya senyawa lain yang menyebabkan warna merah juga ikut terekstrak pada pelarut yang bersifat polar, antara lain antosianin.

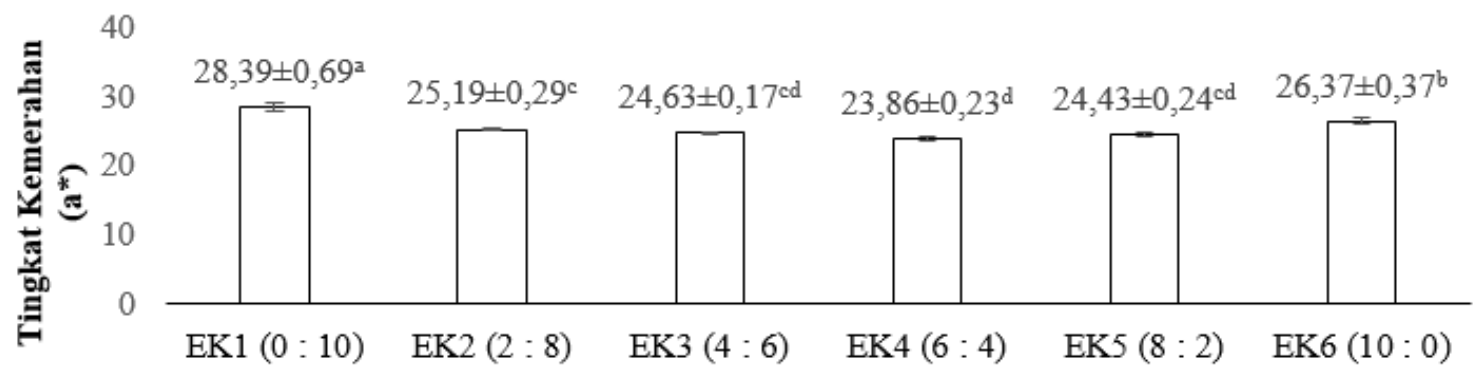

Perbandingan pelarut etanol dan kloroform $(E: K) v / v$

Gambar 5. Grafik nilai rata-rata tingkat kemerahan ekstrak kulit jeruk Mandarin.

Menurut Maulid dan Laily (2015), antosianin adalah pigmen yang larut dalam air yang menyebabkan warna merah, ungu, dan biru serta banyak ditemukan pada buah dan bunga. Pigmen antosianin dapat larut dalam etanol karena antosianin merupakan 
senyawa polar dan etanol merupakan pelarut yang bersifat polar juga (Farida, 2014). Sifat antosianin, termasuk perubahan warna dan aktivitas antioksidan dipengaruhi oleh $\mathrm{pH}$ dan struktur dari antosianin (Março et al., 2011). Março et al. (2011) menyatakan bahwa pada $\mathrm{pH}$ 1-2 antosianin dominan dalam bentuk kation flavilium yang berwarna merah, pada $\mathrm{pH}<6$ berubah menjadi karbinol dan sebagian menjadi kuinonoidal yang berwarna biru sehingga berwarna ungu, pada $\mathrm{pH}$ 6,5-9 dominan kuinonoidal yang berwarna biru, pada $\mathrm{pH}>9$ kalkon yang berwarna kuning.

\section{Tingkat Kekuningan (b*)}

Hasil analisis ragam menunjukkan bahwa perlakuan perbandingan pelarut etanol dan kloroform berpengaruh nyata $(\mathrm{P}<0,05)$ terhadap tingkat kekuningan ekstrak kulit buah jeruk Mandarin. Nilai tingkat kekuningan $\left(b^{*}\right)$ menyatakan tingkat warrna biru sampai kuning dengan kisaran -100 sampai +100. Nilai rata-rata tingkat kekuningan ekstrak kulit buah jeruk Mandarin dapat dilihat pada Gambar 6.

Gambar 6 menunjukkan bahwa nilai ratarata tingkat kekuningan tertinggi diperoleh dari perlakuan perbandingan pelarut etanol dan kloroform (v/v) EK1 (0 : 10) dengan konstanta dielektrikum 6,02 dengan nilai rata-rata 34,52. Sedangkan nilai rata-rata tingkat kekuningan terendah diperoleh dari perlakuan perbandingan pelarut etanol dan kloroform (v/v) EK2 (2:8) dengan konstanta dielektrikum 9,68 dan nilai rata-rata 15,36. Semakin tinggi tingkat kekuningan maka semakin tinggi kadar total karotenoidnya (Sari et al., 2015). Nilai rata-rata tingkat kekuningan pada perlakuan perbandingan pelarut etanol dan kloroform (v/v) EK1 (0 : 10) sudah sesuai dengan pernyataan tersebut, namun pada perlakuan perbandingan etanol dan kloroform (v/v) EK2 (2:8), EK3 (4:6), EK5 (8:2), EK6 (10:0) tidak sesuai dengan pernyataan tersebut. Hal itu dapat disebabkan oleh adanya senyawa lain yang menyebabkan warna kuning dan bersifat lebih polar juga ikut terekstrak. Kulit jeruk mengandung dua jenis pigmen alami dengan polaritas berbeda; salah satunya adalah karotenoid yang larut dalam lemak dan pigmen kuning larut air lainnya (Putnik et al., 2017). Karotenoid yang paling banyak terdapat pada kulit jeruk adalah $\alpha$-karoten, $\beta$-karoten, lutein, zeaxanthin dan $\beta$-cryptoxanthin (Shan, 2016). Lutein dan Zeaxanthin merupakan pigmen pada bahan pangan yang berwarna kuning dan lebih mudah larut dalam air dibandingkan beta-karoten sehingga bersifat lebih polar (Astawan, 2008).

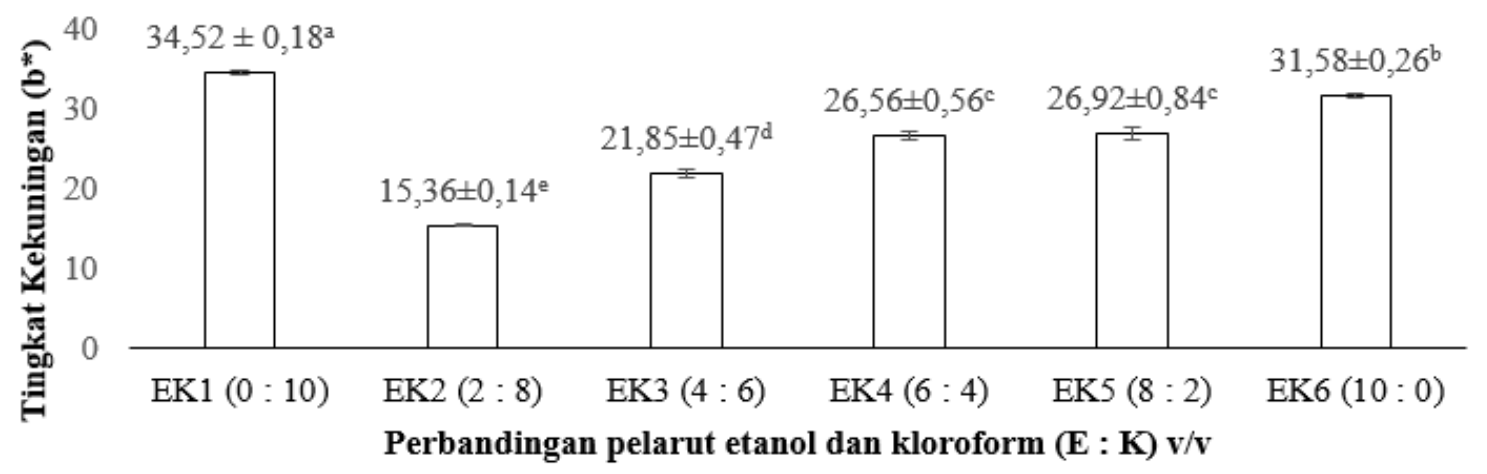

Gambar 6. Grafik nilai rata-rata tingkat kekuningan ekstrak kulit jeruk Mandarin.

Hasil Uji Indeks Efektivitas Produk Ekstrak Kulit Buah Jeruk Mandarin

Uji indeks efektivitas dilakukan untuk menentukan perlakuan terbaik dalam menghasilkan produk ekstrak kulit buah jeruk Mandarin. Variabel yang diamati dalam uji 
indeks efektivitas ini yaitu, rendemen, kadar total karotenoid, tingkat kecerahan, tingkat kemerahan, dan tingkat kekuningan. Hasil uji indeks efektivitas dapat dilihat pada Tabel 1.

Perlakuan terbaik ditunjukkan dengan jumlah nilai tertinggi. Tabel 1 menunjukkan bahwa perlakuan perbandingan pelarut etanol dan kloroform (v/v) EK1 (0:10) mempunyai nilai tertinggi yaitu 0,73 . Hal tersebut menunjukkan bahwa perlakuan perlakuan perbandingan pelarut etanol dan kloroform (v/v) EK1 (0 : 10) merupakan perlakuan terbaik yang dapat menghasilkan produk ekstrak kulit buah jeruk Mandarin, sehingga dapat digunakan sebagai pewarna alami dalam produk pangan, kosmetik maupun industri tekstil namun variabel rendemen diabaikan. Perlakuan alternative yang dapat menghasilkan produk ekstrak kulit buah jeruk mandarin adalah perlakuan perbandingan pelarut etanol dan kloroform (v/v) EK1 (10 : 0) dengan pertimbangan bahwa perlakuan tersebut menghasilkan rendemen ekstrak tertinggi namun variabel kadar total karotenoid diabaikan, sehingga dapat digunakan sebagai pewarna alami pada industri tekstil.

Tabel 1. Hasil uji indeks efektivitas untuk menentukan perlakuan terbaik produk ekstrak kulit buah jeruk Mandarin

\begin{tabular}{|c|c|c|c|c|c|c|c|}
\hline Variabel & & Rendemen & $\begin{array}{c}\text { Kadar } \\
\text { Total } \\
\text { Karotenoid }\end{array}$ & $\begin{array}{c}\text { Tingkat } \\
\text { Kecerahan } \\
\left(L^{*}\right)\end{array}$ & $\begin{array}{c}\text { Tingkat } \\
\text { Kemerahan } \\
\left(\mathrm{a}^{*}\right)\end{array}$ & $\begin{array}{c}\text { Tingkat } \\
\text { Kekuningan } \\
\left(\mathrm{b}^{*}\right)\end{array}$ & Jumlah \\
\hline & (BV) & 4,00 & 5,00 & 1,20 & 0,60 & 3,00 & 15,00 \\
\hline & (BN) & 0,27 & 0,33 & 0,08 & 0,20 & 0,12 & 1,00 \\
\hline $\begin{array}{c}\text { Etanol: } \\
\text { Kloroform }\end{array}$ & $\mathrm{Ne}$ & 0,00 & 1,00 & 1,00 & 1,00 & 1,00 & \\
\hline$(0: 10)$ & $\mathrm{Nh}$ & 0,00 & 0,33 & 0,08 & 0,20 & 0,12 & 0,73 \\
\hline $\begin{array}{c}\text { Etanol: } \\
\text { Kloroform }\end{array}$ & $\mathrm{Ne}$ & 0,28 & 0,26 & 0,75 & 0,29 & 0,00 & \\
\hline$(2: 8)$ & $\mathrm{Nh}$ & 0,07 & 0,09 & 0,06 & 0,06 & 0,00 & 0,28 \\
\hline $\begin{array}{c}\text { Etanol: } \\
\text { Kloroform }\end{array}$ & $\mathrm{Ne}$ & 0,56 & 0,18 & 0,54 & 0,17 & 0,34 & \\
\hline$(4: 6)$ & $\mathrm{Nh}$ & 0,15 & 0,06 & 0,04 & 0,03 & 0,04 & 0,33 \\
\hline $\begin{array}{c}\text { Etanol: } \\
\text { Kloroform }\end{array}$ & $\mathrm{Ne}$ & 0,89 & 0,13 & 0,14 & 0,00 & 0,58 & \\
\hline$(6: 4)$ & $\mathrm{Nh}$ & 0,24 & 0,04 & 0,01 & 0,00 & 0,07 & 0,36 \\
\hline $\begin{array}{c}\text { Etanol: } \\
\text { Kloroform }\end{array}$ & $\mathrm{Ne}$ & 0,95 & 0,09 & 0,07 & 0,13 & 0,60 & \\
\hline$(8: 2)$ & $\mathrm{Nh}$ & 0,25 & 0,03 & 0,01 & 0,03 & 0,07 & 0,39 \\
\hline $\begin{array}{c}\text { Etanol: } \\
\text { Kloroform }\end{array}$ & $\mathrm{Ne}$ & 1,00 & 0,00 & 0,00 & 0,55 & 0,85 & \\
\hline$(10: 0)$ & $\mathrm{Nh}$ & 0,27 & 0,00 & 0,00 & 0,11 & 0,10 & 0,48 \\
\hline
\end{tabular}

Keterangan: $\mathrm{Ne}=$ nilai efektivitas

$\mathrm{Nh}=$ nilai hasil $(\mathrm{Ne} \times \mathrm{BN})$

\section{KESIMPULAN}

\section{Kesimpulan}

Berdasarkan penelitian yang telah dilakukan maka dapat disimpulkan beberapa hal sebagai berikut:

Perbandingan pelarut etanol dan kloroform berpengaruh nyata terhadap rendemen, kadar

$$
\begin{aligned}
& \mathrm{BV}=\text { bobot variabel } \\
& \mathrm{BN}=\text { bobot normal }
\end{aligned}
$$

total karotenoid, tingkat kecerahan $\left(\mathrm{L}^{*}\right)$, tingkat kemerahan $\left(\mathrm{a}^{*}\right)$, dan tingkat kekuningan $\left(b^{*}\right)$ ekstrak kulit buah jeruk Mandarin.

Perbandingan etanol dan kloroform (0 : 10) $\mathrm{v} / \mathrm{v}$ merupakan perlakuan terbaik untuk menghasilkan ekstrak kulit buah jeruk Mandarin dengan karakteristik rendemen 
$4,83 \pm 0,22 \mathrm{f}(\%)$, kadar total karotenoid $3,56 \pm 0,20 \mathrm{a}(\%)$, tingkat kecerahan $\left(\mathrm{L}^{*}\right)$ $31,34 \pm 0,63 \mathrm{~d}$, tingkat kemerahan $\left(\mathrm{a}^{*}\right)$ $28,39 \pm 0,69 \mathrm{a}$, dan tingkat kekuningan $\left(\mathrm{b}^{*}\right)$ $34,52 \pm 0,18$ a.

\section{Saran}

Berdasarkan hasil penelitian ini dapat disarankan sebagai berikut :

Perlu dilakukan penelitian lebih lanjut dengan menggunakan kombinasi beberapa jenis pelarut selain etanol dan klorofrom pada ekstraksi pewarna dari kulit buah jeruk Mandarin yang memungkinkan menghasilkan hasil yang lebih baik dan aplikasinya pada produk pangan, kometik dan industri tekstil.

\section{DAFTAR PUSTAKA}

Adiyasa, I. K. G. P., L. P. Wrasiati, dan N. M. Wartini. 2015. Efektivitas Jenis Pelarut Dalam Lama Ekstraksi terhadap Karakteristik Concrete Minyak Atsiri Kulit Jeruk Mandarin (Citrus reticulata). Jurnal Rekayasa dan Manajemen Agroindustri 3(4):21-29.

AOAC. 1999. Official Methods of Analysis $\left(15^{\text {th }}\right.$ Ed.). K. Helrich (Ed). Virginia.

Astawan, M. 2008. Khasiat warna - warni makanan. Gramedia Pustaka Utama. Jakarta.

Berutu, L. S. 2013. Pengaruh Ukuran Partikel dan Lama Ekstraksi Terhadap Karakteristik Ekstrak Kulit Buah Manggis (Garcinia mangostana L.). Skripsi. Tidak DipublJurusan Teknologi Industri Pertanian, Fakultas Teknologi Pertanian, Universitas Udayana, Bukit Jimbaran.

Farida, R. (2014). Ekstraksi antosianin limbah kulit manggis metode microwave assisted extraction (lama ekstraksi dan rasio bahan : pelarut). Jurnal Pangan dan Agroindustri 3(2):362-373.
Husnah, M., H. Baroroh., dan E. K. Hayati. 2009. Identifikasi dan uji aktivitas golongan senyawa antioksidan ekstrak kasar buah pepino (Solanum muricatum Aiton) berdasarkan variasi pelarut. Jurnal Kimia 1(1):1-6.

Isadora, N.K.M., N.M. Wartini dan N. S. Antara. 2016. Pengaruh Kombinasi Jenis Pelarut dan Perbandingannya Terhadap Karakteristik Ekstrak Buah Pandan (Pandanus tectorius). Jurnal Rekayasa dan Manajemen Agoindustri 4(3):47-58.

Março, P.H., Ronei J.P., Ieda S.S., and Romà T. 2011. Investigation of the $\mathrm{pH}$ effect and UV radiation on kinetic degradation of anthocyanin mixtures extracted from Hibiscus acetosella. J. Food Chem. 125(3):1020-027.

Maulid, R. R. dan A. N. Laily. 2015. Kadar total pigmen klorofil dan senyawa antosianin ekstrak kastuba (Euphorbia pulcherrima) berdasarkan umur daun. Jurnal Prosiding KPSDA 1(1):225-230.

Muchtadi, D. 1989. Evaluasi Nilai Gizi Pangan. Departemen Pendidikan dan Kebudayaan Direktorat Jenderal Pendidikan Tinggi Pusat Antar Universitas Pangan dan Gizi. Institut Pertanian Bogor, Bogor.

Nogata, Y., K. Sakamoto., H. Shiratsuchi., T. Ishii., M. Yano., and H. Ohta. 2006. Flavonoid composition of fruit tissues of citrus species. Biosci. Biotechnol. Biochem. 70(1):178-192.

Putnik, P., D. B. Kovačević., A. R. Jambrak., F. J. Barba., G. Craotto., A. Binello., J. M. Lorenzo., A. Shpigelman. 2017. Innovative "Green" and Novel Strategies for the Extraction of Bioactive Added Value Compounds from Citrus Wastes: A Review. MDPI: Journal Molecules. http://www.mdpi.com/14203049/22/5/680/pdf. Diakses pada tanggal 8 Agustus 2018. 
Sari, N. G. A. K. R. P., N. M. Wartini., dan I. W. G. S. Yoga. 2015. Pengaruh Jenis Pelarut Terhadap Rendemen dan Karakteristik Ekstrak Pewarna Dari Buah Pandan (Pandanus tectorius). Jurnal Rekayasa dan Manajemen Agroindustri 3(4):103-112.

Satriyanto, B., S. B. Widjanarko., dan Yunianta. 2012. Stabilitas warna ekstrak buah merah (Pandanus conoideus) terhdap pemanasan sebagai sumber potensial pigmen alami. Jurnal Teknologi Pertanian 13(3):157-168.

Shan, Y. 2016. Comprehensive Utilization of Citrus By-products; Academic Press:
Cambridge, MA, USA.

Silalahi, S.E., L.P. Wrasiati., dan A.A.M.D. Anggreni. 2014. Karakteristik Bubuk Ekstrak Kulit Buah Jeruk Mandarin (Citrus reticulata) Pada Perlakuan Lama Maserasi dan Konsentrasi Maltodekstrin. Jurnal Rekayasa dan Manajemen Agroindustri 3(2):73-81.

Sudarmadji, S., B. Haryono, dan Suhardi. 1989. Analisa Bahan Makanan dan Pertanian. Liberty, Yogyakarta.

Weaver, C. 1996. The Food Chemistry Laboratory. CRC Press, Boca Raton, New York, London, Tokyo. 